\title{
Cure, Community, and the Miraculous in Early Modern Florence
}

\author{
Jenni Kuuliala
}

Illness and impairment, like bodily and mental deviance, are fundamental aspects of human life and something that each society has to negotiate. 'Health' - or the lack of it - is a social construct, and it has varied from society to society over time. In early modern Europe, health largely referred to one's ability to fulfil one's social role; a 'full cure' in the sense a modern person would understand it was not necessarily even the main expectation of an infirm person. ${ }^{1}$ Similarly, the favouring and acceptability of various curative methods and their usage was negotiated within families and communities. Medical pluralism was prevalent: various healing methods - be they based on university-trained medicine, religion, or so-called folk healing practices - were used simultaneously, and their borders overlapped.

The medical pluralism of the Renaissance and early modern Europe has been well documented in many types of sources. Among the most fruitful are the witness depositions of canonisation inquiries, which record views on infirmity, healing, and the miraculous.

Canonisation processes were initiated by the papacy in the early thirteenth century in order to gain more control of the veneration of saints, and over the following centuries, the procedure was established, strengthened, and renewed. ${ }^{2}$ During the inquests, the life, merits, and deeds of a putative saint were investigated, and the records were evaluated by the auditori of the Rota. The witness inquiries were executed following propositions called the articuli. Produced by the procurator of the case, they recorded the saintly candidate's life and miracles, which the witnesses were asked to provide evidence of, and which therefore largely shaped the witness accounts. ${ }^{3}$ Furthermore, the witnesses' views were influenced by culturally established ideas about sainthood and miracles. ${ }^{4}$ Thus, the testimonies are an

\footnotetext{
${ }^{1}$ Gentilcore $1998,185-86$.

${ }^{2}$ See Klaniczay 2004; Paciocco 2006; Vauchez 1988 for the development and legal practices of medieval canonisation inquiries. The developments during the Catholic Reformation have been analysed, e.g. in Burke 1987; Copeland 2016a; Copeland 2016b; Ditchfield 1995; Ditchfield 2009; Ditchfield 2010; Duffin 2009; Papa 2001. See also the Introduction to this volume for the development of the process.

${ }^{3}$ Ditchfield 2010, 420-21. Most canonisation inquiries at this point had two stages: the 'informative', which was taken care of locally, and the 'apostolic', which was authenticated by the pope on the grounds of the first hearing. See e.g. Papa 2001, 150-65.

${ }^{4}$ See Goodich 2005; Smoller 1998 for finding the witnesses' voices in these documents.
} 
illuminative example of the interplay of everyday life, rituals, and the legal and theological principles of organised religion - that is, the fundamental aspects of early modern lived religion. $^{5}$

Over the course of time and especially in the aftermath of the Council of Trent, the juridical and medical requirements for the proof of miracles became ever more important. ${ }^{6}$ Increasing care was taken in defining and labelling the supernatural. ${ }^{7}$ In this, the most crucial aspect for the current topic is the growing importance of medical science. Following biblical examples, the vast majority of recorded miracles were cures, while non-healing miracles made up a minority of such events. The late medieval canonisation protocols mainly concentrate on miracles healing various acute and long-term conditions. ${ }^{8}$ During the Catholic Reformation, the proportion of miraculous cures increased further, as did the role of medical professionals and medical science in investigating and evaluating the alleged miracles. These changes reached their peak in the eighteenth century, but the tendency to give increasing importance to medical expertise is already visible in the early seventeenth century hearings. ${ }^{9}$

This chapter will investigate the communal nature of medical and religious healing using the apostolic canonisation inquest records of St Andrea Corsini (1306-1374), produced in Florence in early 1606, as a source. Andrea Corsini was first a Florentine Carmelite prior and then the bishop of Fiesole, and he died in an odour of sanctity. His most important miracle was reported to have occurred in 1440, when he intervened in the Battle of Anghiari in favour of the Florentine forces and against those of the Duke of Milan. Consequently, he was beatified by Pope Eugene IV in $1440 .{ }^{10}$ Originally, his fama was limited to the order, which promoted it mainly orally, and to the areas around Fiesole and Florence. In the latter half of the sixteenth century, Andrea's life was added to two major collections of saints' vitae, which helped in spreading his cult. There were petitions for his canonisation during the papacy of Paul II (1464-1471), but although the cause was considered, nothing came of it. Finally, after further petitions by the Carmelite order, the Florentine people, the Corsini family, Grand

\footnotetext{
${ }^{5}$ See Katajala-Peltomaa \& Toivo 2016.

${ }^{6}$ See the Introduction to this volume for further discussion.

${ }^{7}$ Burke 1987, 50-51.

${ }^{8}$ Vauchez 1988, 547.

${ }^{9}$ Duffin 2009, 17-33, 114-16.

${ }^{10}$ Andrea's cult and the importance of the battle are analysed in Ciappelli 2007.
} 
Duke Ferdinando I de' Medici, and King Henry IV of France, his canonisation process was initiated during the papacy of Clement VIII (1592-1605) and continued by Paul V. ${ }^{11}$ He was finally canonised in 1629 by Urban VIII.

During the apostolic canonisation investigation, 140 witnesses were interrogated. The protocols of the inquest, preserved in the Archivio Segreto Vaticano (hereafter ASV) manuscript Congregazione dei Riti, Processus 762, record a rather uniform picture of Andrea Corsini's life, which the witnesses generally explained they knew because of his written vitae. The records also contain testimonies to 62 miracles. They were all investigated in detail with several witnesses for each case. Consequently, the process is situated in a transition period, as there was move away from investigating large amounts of miracles to investigating only a few. ${ }^{12}$ After all, despite the changes initiated at the council of Trent, the canonisations at the turn of the seventeenth century were still largely conducted according to the medieval procedure. ${ }^{13}$ In the following, I focus on the role of the community in the search for cures as portrayed in these testimonies. How was the need for a cure defined? Given the developments of the era detailed in the process, an important concept is the medicalisation of the miraculous. How often were physicians and their diagnoses involved, and did medical language play an important role in defining a condition that needed saintly intervention? As noted, the role of the community in the search for a cure is also an important matter. Whose healing acts were recorded, who decided on the methods, and what role did the community members play?

\section{Community and the cult}

Traditionally, those conducting canonisation inquests preferred witnesses from relatively wealthy backgrounds, especially when interrogating them about the putative saint's life. ${ }^{14}$ In the post-Tridentine inquests, the social status of those testifying about their miraculous cures varies greatly, although the witnesses still had to be of good reputation, and extremely poor people like beggars rarely make an appearance. There was variation in the groups that

\footnotetext{
${ }^{11}$ Ciappelli 2007, 40-52. See also Copeland 2016a, 109; Cristofani, Vita di S. Andrea Corsini, 35.

12 See Duffin 2009, 20, 46-47.

${ }^{13}$ Ditchfield 2010, 419-21.

${ }^{14}$ Ciappelli 2007, 54. The preference given to wealthy witnesses was ordered in the decretals of Gregory IX. Krötzl 1998, 122-23.
} 
identified with the cults, ${ }^{15}$ but since the witnesses in canonisation processes do not statistically represent the real-life situation, it is difficult to draw far-reaching conclusions about the cult's status among different social groups. ${ }^{16}$ In St Andrea Corsini's inquest, surprisingly many witnesses categorized themselves as 'poor', although there is quite a lot of deviation in what 'poor' actually means. ${ }^{17}$ A large part of them were workers in the wool trade, whose economic situation varied, but among the witnesses labelling themselves 'poor' there are also gold-beaters and servants, for example. ${ }^{18}$ About one third of the witnesses were religiosi and members of the secular elite, including 15 senatori - that is around one third of the members of the senate of the grand duchy. ${ }^{19}$ These witnesses mostly testified about Andrea Corsini's fama publica, while miraculous cures of the members of the (secular) elite were quite sparsely recorded. ${ }^{20}$ The most notorious of such miracles is perhaps the cure of magnifica domina Elisabetta Seraglia of demonic possession. She was also cured of fever, and her daughter was cured of an ear ailment. Furthermore, the son of a senator was cured of fever, and one noblewoman reported her rescue of a difficult childbirth. ${ }^{21}$

Most of the elite witnesses were asked the standard question about Andrea Corsini's miracles, but they replied that they knew the miracles had occurred and only reported older, established miracles they had heard or read in his vitae; the most common ones being the healing of a blind man in Avignon and the saintly intervention in the Battle of Anghiari. ${ }^{22}$ Some of the non-elite witnesses reporting a contemporary miracle equally began their response to the question about Andrea's miracles with similar answers, although usually in

\footnotetext{
${ }^{15}$ See Duffin 2006, 38.

${ }^{16}$ The first inquests into the miracles of St Caterina Vigri (or Catherine of Bologna) from the late sixteenth century are a good example of witnesses quite different from those in Andrea Corsini's inquest. The vast majority of them came from the secular elite. Martinelli 2003, 20-76.

${ }^{17}$ See also Duffin 2006, 47. For such notifications, see e.g. ASV Riti Proc. 762, f. 84r: 'son pouera, et uiuo a spese del mio marito che e' Scuffarolo'; f. 92 r: 'et son pouero che il mio non puol valere più di 50 o' 60 ducati per essere pouero tessitore di lana et vivo delle mie fatiche et alle mie spese'; f. 170r: 'son pouera che la mia dose sonno sino a'ducento Ducati et vivo delle mie fatiche'.

${ }^{18}$ For the history of such groups of workers in Renaissance Florence, see e.g. Goldthwaite 2009; Cohn 1980. Goldwaithe 2009, 268, points out that the economy of the sixteenth and seventeenth centuries has received much less scholarly attention than the economy of the high Renaissance period.

${ }^{19}$ Ciappelli 2007, 54.

${ }^{20}$ See Kuuliala 2015 for this phenomenon in the Middle Ages.

${ }^{21}$ See pages \#\#\# below for a discussion of these cases.

${ }^{22}$ For example, a Florentine Archdeacon on ASV, Riti Proc. 762, f. 13r; a nobleman on f. 19v; a senator on f. $42 \mathrm{r}$; a Jesuit brother on f. $60 \mathrm{v}$; another senator and nobleman on f. $216 \mathrm{v}$.
} 
less detail. ${ }^{23}$ Simon Ditchfield has explained these kinds of references with the 'care and circumspection' that was attributed to the growing importance of proving the miraculous. ${ }^{24}$ Since it is probable that many of the elite witnesses were summoned to testify precisely because of their status and the value of their knowledge about the cult instead of a particular miracle, the testimonies do not prove that these witnesses were more careful in reporting miracles. What is clear, however, is that the witnesses knew that referring to the long-existing cult and the older hagiographic narratives provided the grounds for their testimony.

St Andrea's cult was promoted by the clerical and secular elite, whose testimonies gave proof of its existence on a general level. At the same time, without the veneration and propagation of the cult among the Florentine population at the grass-roots level, there would have been no fama publica. Many of the witnesses were related to each other, and there were families in which more than one miraculous cure was attributed to St Andrea's powers. Since a noticeably high number of witnesses belonged to the community of Florentine wool trade workers, this was one of the communities in which the lived religious practices related to the veneration of St Andrea was a vital element. Admittedly, the number of people working in the wool trade constituted a significant portion of Florence's estimated population of 60,000 70,000 inhabitants, so it is perhaps no surprise that their number is high in the hearing as well. Nevertheless, the Corsinis had made their fortune as wool merchants in late medieval Florence, which connects the saint to this particular trade..$^{25}$ Lived religion was a core element of families and communities, and the veneration of saints was a crucial part of it; therefore, it is only natural that certain cults gained prestige within certain communities, whose members passed on information about the particular saint's deeds.

In addition to social status, other factors also had an impact on the selection of witnesses and the miracles chosen for investigation, not to mention the social dimensions of the cult. Gender is one of them. Of the 114 witness accounts, 61 were given by men (one of them

\footnotetext{
${ }^{23}$ See e.g. the testimony of a noblewoman miraculously saved from a dangerous childbirth: ASV, Riti Proc. 762, f. 302r: 'ho' sentito dire publicamente, et letto anchora che il beato Andrea ha fatto molti miracoli delli quali hora non mi ricordo ma' ve ne diri alcuni che mi ricordo, et sonno che illumina un Ceco in Avignone che gli chiedeva l'elemosina, et guari una fanciulla dalla febre ethica, guari ancora un frate nel Carmine della hidropsia et molti altri che sonno descritti nella sua vita'.

${ }^{24}$ Ditchfield 2009, 567. The miracles are recorded in Petrus Andrea de Castaneis, Vita, Societé des Bollandistes, ed. 1863-. Acta sanctorum quotquot toto urbe coluntur, Jan II, 1067-68, 1070.

${ }^{25}$ The Arte della Lana guild had some prestigious privileges in the city's religious life, like the administration of the Duomo's sacristy. Tacconi 2005, 25-26.
} 
testifying twice) and 53 by women. Among the elite witnesses testifying primarily about the saint's fama, a larger proportion were men. As for the miraculées, 28 were male and 31 were female (two of them experienced a miracle twice), excluding the reported 'group cure' of 40 nuns. Twelve of the beneficiaries were children. Jacalyn Duffin's research has shown that before the late eighteenth century, miracles with male beneficiaries were a little more common, generally speaking, while the proportion of female miraculées increased after the turn of the century. ${ }^{26}$ Therefore, the figures for Andrea Corsini's hearing are somewhat exceptional, but at the same time, it is important to bear in mind that the miracles and witnesses in canonisation hearings have always been a selection, and the sex ratios do not reflect the real life situation, but rather the preference of those conducting the hearings. ${ }^{27}$

Another question regarding the selection of witnesses is that of the infirmities miraculously cured. A shift in the proportions of healing miracles took place in the late Middle Ages, when cures of acute, dangerous conditions became more common and the proportion of long-term disabling conditions decreased, especially those labelled as contracti, 'crippled'. This tendency becomes even more notable in the early modern processes. ${ }^{28}$ In Andrea Corsini's inquest, most infirmities the miraculées were cured of were indeed relatively short-term illnesses, such as fever and flux, or the miraculées were rescued from various accidents. Furthermore, the number of miracles related to childbirth, at eleven, is exceptionally high. ${ }^{29}$ Cures of acute conditions were considered easier to prove, and the figures did not necessarily reflect the reasons for imploring the saints' help in real-life situations. As pointed out by David Gentilcore, in miracle collections with less high-ranking clerical control, the

\footnotetext{
${ }^{26}$ Duffin 2009, 52-53.

${ }^{27}$ Overall, official sainthood was notably male in the Catholic Reformation period in the sense that the vast majority of canonised saints were men. Only in the nineteenth century did the proportion of canonized female saints start to increase significantly. Burke 1987; Duffin 2009, 51-52. At the same time, many of the most universally recognized saints were women, the Virgin being the most obvious example, and several medieval female saints - such as St Clare of Assisi or St Catherine of Siena, who was the 'model saint' for aspiring holy women - were widely venerated. See Debby 2014.

${ }^{28}$ See the Introduction of this volume, page \#\#\#. For the proportions of various conditions in sixteenth-century French cases, see Burkardt 2004, 192-95, 207-211, 229-35; his categorization for 'contracti' is different, since in his analysis of women's conditions, he groups it together with infirmities such as colic, hernia, and melancholy.

${ }^{29}$ This aspect of Andrea's cult was mentioned in the testimony of one witness, whose wife was a beneficiary of such a miracle. ASV, Riti Proc. 762, f. 101v: 'Et adesso riposano la sua Reliquie a' Donne grauide le quali Reliquie fanno molto bene, et indiuono questa Donne a' partorire quasi senza dolore'. According to Jacalyn Duffin 2009, 90-92, the percentage of obstetric miracles (those related to childbirth, fertility, and post-partum problems) in the seventeenth-century canonisation processes is 4.7 . The number of miracles related to childbirth and especially post-partum fever reduced only in the latter third of the nineteenth century.
} 
proportion of long-term disabling conditions is higher than in canonisation proceedings. ${ }^{30}$ Indeed, the type of miracles chosen for record resulted from a complex procedure in which the practicalities of the cult, hagiographic conventions, legal requirements, and the personal preferences of those investigating the cases were at play. In Andrea Corsini's inquest, 'traditional' impairments as well as other long-term, chronic conditions were investigated. For example, one woman was cured of the deafness she had suffered for two years, ${ }^{31}$ a boy had his sight restored after having been blind for a year, ${ }^{32}$ and another boy was cured of the crepatus he had endured for half a year. ${ }^{33}$ Like the saints in general, St Andrea was believed to have healed a large array of physical and mental infirmities.

\section{The need for a cure}

The need for a thaumaturgic cure is a self-evident presupposition in any healing miracle included in the established narrative pattern. ${ }^{34}$ These aspects were investigated during canonisation trials, since without a hopeless situation there could have been no miracle. Articulus number sixteen in Andrea Corsini's inquest includes a question about the type of illness, the duration of the infirmity, other particularities, and the manner in which the miraculous cure was obtained. ${ }^{35}$ As significant emphasis was placed on scientific examination, the records favour matter-of-fact responses to such questions. Witnesses to Andrea Corsini's hearing gave medical diagnoses for their conditions, but despite the prestige given to medical science, the aetiology is mostly missing and references to humoral theory are rare. ${ }^{36}$ The type and the name of the condition were the required information. For example, magister Andrea Pelli Carmelita stated that for three days, he was unable to speak, drink, or eat due to an infirmity. The name of the illness puzzled the interrogators, who

\footnotetext{
${ }^{30}$ Gentilcore 1998, 194-95.

${ }^{31}$ ASV Riti Proc. 762, f. 255r-v.

${ }^{32}$ ASV Riti Proc. 762, f. 92v-93r, 116v, 122v.

${ }^{33}$ ASV Riti Proc. 762, f. 125r, 160r.

${ }^{34}$ The literary pattern of the miraculous was inherited from the Gospels. Ward 1982, 34-35. For the narrative structure, see Goodich 2007, 93-99; Klaniczay 2000.

${ }^{35}$ ASV Riti Proc. 762, f. 21v, art. 16: 'quo morbo vel egritudine laboraret quando factum fuit miraculum et a' quanto tempore predicta Infirmitate laboraret et exprimas singulas circumstantias et interrogetur, qua occasione habuit recursum ad predictum beatum Andream, et an a' se ipso motus vel ab aliis fuerit inditus ut se ipsius Intercessioni commendaret, et qui essent presentes, quando fuit factum miraculum si autem Testis narret miraculum in alterius persona'.

${ }^{36}$ In this, the testimonies are very similar to medieval miracle narratives. See Sigal 1985, 288. There are exceptions, of course; humours as the cause of infirmity are sporadically mentioned: ASV Riti Proc. 762, f. 88r, $133 \mathrm{v}, 181 \mathrm{v}$.
} 
inquired about it. Another witness to the miracle replied that he did not know the name because the physicians did not know it either, ${ }^{37}$ which apparently validated the witnesses' ignorance. Usually the witnesses were able to give a diagnosis, however. The painter Laurentius (or Lorenzo) Cresci testified that he first had tertiary fever, which then turned into quartan fever, which caused flux, male di fianche, and other, unnamed infirmities. ${ }^{38}$

Many witness accounts from the seventeenth century are lacking the colourful portrayals of suffering and disability that we encounter in late medieval miracle narratives. ${ }^{39}$ Although the miracles and incurable situations were a sensory and a corporeal experience, these aspects were not of great interest to those conducting the inquiries. The chief physical markers of a severe incurable condition had remained more or less the same since medieval times: in addition to the diagnosis, witnesses reported functional hindrances and occasionally pain. Perhaps because of the rarity of orthopaedic impairments, traditional detailed narratives about mobility problems are rare in the records of Andrea Corsini's hearing, although undoubtedly they were as much a part of the experiences of many infirm people as they were before. An exception is the testimony of a servant to the ducal household who suffered from paralysis; he needed his wife's assistance to get from one place to another. ${ }^{40} \mathrm{~A}$ few witnesses also mentioned the infirm person's inability to get out of bed, ${ }^{41}$ which is a topos-like way of defining serious infirmity in the hagiographic context. This kind of information was not necessary for the inquest, however, as the diagnosis alone could be sufficient. ${ }^{42}$

The articles in Andrea Corsini's hearing also include a question about whether 'human remedies' (humanis remediis) had been used, if they had proven futile, and how long prior to the miracle they had been used. ${ }^{43}$ Of course, the purpose of the question was to secure that the healing could not have been obtained by any earthly means. In virtually all miracle narratives, one or more witnesses referred to medical treatment, but unlike in some

\footnotetext{
${ }^{37}$ ASV Riti Proc. 762, f. 9v, 26r.

${ }^{38}$ ASV Riti Proc. 762, f. 23r.

39 This is not to say that medieval canonisation testimonies were 'unscientific' according to the standards of the time. Rigorous examination was needed and expected then as well, but the practices of recording witness accounts were much more colourful and varied.

${ }^{40}$ ASV Riti Proc. 762, f. 210r; see also 165v for a boy who needed the help of others to rise from bed.

${ }^{41}$ ASV Riti Proc. 762, f. 32r, 185v, 200r, 257v; being able to get up from bed could also be a sign of a miracle; see f. $98 \mathrm{r}$.

42 One man, who had several ulcers on his leg for ten years, did not report any mobility issues. His son's account of the same miracle is equally brief. ASV Riti Proc. 762, f. 63r, 83r.

${ }^{43}$ ASV Riti Proc. 762, f. 21r, art. 14.
} 
contemporary inquests, only one medical professional testified about Andrea Corsini's cures. ${ }^{44}$ Responses to the question are nevertheless telling about the Florentine community's mentalities regarding the interplay of medical and religious health care. In most statements, the diagnosis merges with the futile medical help. For example, Lorenzo Cresci's testimony mentions other ills the fever caused, and then continues by stating that the fever remained despite the fact that he had used medicine prescribed by the physicians. ${ }^{45}$ Another miraculé, Leonardus Sancti Bonaceine, was unable to urinate due to carnositas. He similarly moved from describing this condition to reporting how he had asked a surgeon to come, but the treatment made him worse. ${ }^{46}$ In these cases, the failure of earthly medicine becomes part of the infirmity calling for saintly intervention. It is impossible to reconstruct the actual inquest situation, but the way the statements are recorded gives an impression that the witnesses inter-connected their ailment, its severity, and the usage of medical treatment.

Despite the medical developments and requirements in the period, not every infirmity cured by St Andrea's merits was treated by 'official' medical practitioners. ${ }^{47}$ Reports of no medicine being given were made in the case of a small child suffering from epilepsy. According to the boy's father, this was because boy was considered dead. An acquaintance stated that the reason no medicine was given was because the boy was considered too young to handle it. ${ }^{48}$ Sometimes physicians were present but still no medicine was used, as in the case of a woman who had a severe postpartum condition that they deemed fatal. According to her own testimony, she did not take any medicine because she did not want to. ${ }^{49}$ For the canonisation inquest, it was crucial to establish the amount of time that had elapsed between the usage of medicina and the cure in order to be confident that saintly intervention was indeed the cause. The witnesses' responses to this question sometimes reveal that they lived

\footnotetext{
${ }^{44}$ Claudius Coecchius, a surgeon (ASV Riti Proc. 762, f. 231r), testified about the childbirth of magnifica domina Dionora. The other medical professionals who testified in the inquiry did so as regards the saint's incorruptible body. This was a typical role given to medical experts in early modern apostolic canonisation processes. Bouley 2017, esp. 76-77.

${ }^{45}$ ASV Riti Proc. 762, f. 23r.

${ }^{46}$ ASV Riti Proc. 762, f. 31r: 'non potette mai urinare per la Carnosia che io havevo et stette cosi seno alla mattina seguente, che mandai a' chiamare un Cirurgico che mi servingo et mi fece molto male'.

47 There are some contemporary indicators that congenital mobility impairments and malformations were not treated by medical professionals due to them being considered incurable, but since such cures were not recorded in Andrea Corsini's inquest, comparisons cannot be made. In a vita of St Carlo Borromeo, the author explains the lack of medical care in the case of a small girl with congenitally twisted feet by her being 'born that way' (per essere nata in quel modo): Giussani, Vita di s. Carlo, 672.

${ }^{48}$ ASV Riti Proc. 762, f. 17v, 113r, 120r.

${ }^{49}$ ASV Riti Proc. 762, f. 85v;
} 
with their infirmity for a long time after treatment had proven useless. For example, the lay nun Angelica de Castel del Rio had 'leprous' hands for thirty years. She testified that she did not remember exactly how long it took between trying 'many medicines' (molte medicine) and the miracle, but she estimated it was many years. Another witness claimed that it was four years. ${ }^{50}$

Sometimes the explanation given for not using 'medicine' (by which the witnesses meant medical treatment given by physicians or surgeons) was economic. This is demonstrated by the testimony of Bartholomea Petri de Sancto Donino, who had had a severe ailment of the head. She had tried 'water of chicory' but testified she did not use any (other) medicine, because she could not afford it. Her husband testified that she did not want to go to a hospital. ${ }^{51}$ This would have been one way to receive medical treatment, as the hospitals of Florence tended to the poor of good reputation. ${ }^{52}$ Memories regarding the financial aspects of the physicians' treatment could be somewhat vague among the witnesses, though. A boy called Agostino had bled from his nose and mouth for a month due to what physicians labelled rissipola (translatable as 'erysipelas', but probably covering a variety of conditions). According to his mother, Antonia Bartholomei Battioloro - a gold-beater's widow - and his brother Julius, physicians visited the boy but they did not want to medicate him, because they considered him to be a 'lost' case. ${ }^{53}$ Here they acted according to the principles of their profession, as doctors were not supposed to promise too much. ${ }^{54}$ At the same time, Agostino's sister Bartolomea connected the lack of medical treatment with the family being unable to afford it: ${ }^{55}$ both she and her mother categorised themselves as 'poor'. The father had died, so the two women provided for themselves by making knitted iron socks, and Agostino was sent to his godfather to learn his father's profession.

Long-term infirmity and treatment could indeed place a significant economic strain on a family. One of the witnesses, Catharina Angeli Ricci, a worker in the silk trade, was outspoken on the matter. She described herself as 'very poor' (poverissima) because her

\footnotetext{
${ }^{50}$ ASV Riti Proc. 762, f. 78v, 133v.

${ }^{51}$ ASV Riti Proc. 762, f. 38r-v, 76r.

${ }^{52}$ Henderson 2006, 270-74.

${ }^{53}$ ASV Riti Proc. 762, f. 88r, 233v.

${ }^{54}$ Ziegler 1999, 217. See also Pomata 1998.

${ }^{55}$ ASV Riti Proc. 762, f. 106v: 'nel male del mio fratello non funno adoprate medicine alcune per non hauere il mondo di pagare il medico ne le medicine'.
} 
husband had been ill for seven years; she used whatever little money she had to combat the illness that eventually led to his demise. ${ }^{56}$ When an infirmity severely tested a family's economic situation, St Andrea Corsini's intervention could cure much more than 'just' an illness; it could save the whole family. Although such references were perhaps not in accordance with the Catholic Reformation-era preference for scientific evidence, they were still clearly valued as proof of the miraculous power of the putative saint and were presented as such by the witnesses.

The witnesses could also manifest the need for saintly intercession when threatened by permanent disability, even when reporting about acute, dangerous conditions. One mother prayed that her son, who had been run over by a carriage, would 'live not remaining crippled' (vivere non restasse stroppiato) ${ }^{57}$ In a testimony about another miracle, the painter Bernardino Puccetti (or Poccetti, 1548-1612) was painting St Andrea's image and fell from his ladder. He could not feel a thing and was sure he would remain 'crippled'. Prayers to the very painting he was working on cured him. ${ }^{58}$ The fear of long-term disability was also mentioned by a man with an abscess on his knee, ${ }^{59}$ as well as by some witnesses testifying about cures of eye conditions. ${ }^{60}$ These fears could also be related to the medical treatment proposed; according to her brother, the wife of Lorenzo Cresci did not want physicians to cauterise her ailing hand for the fear of 'remaining crippled' (restare stroppiata). ${ }^{61}$ Thus, although long-term disabilities are relatively rare in Catholic Reformation-era hearings, the possibility and fear of them remained an important manifestation of a miraculously cured condition, and something that was later recalled, in part strengthening the saint's fama.

\footnotetext{
${ }^{56}$ ASV Riti Proc. 762, f. 27v.

${ }^{57}$ ASV Riti Proc. 762, f. 135v.

${ }^{58}$ ASV Riti Proc. 762, f. 220r: 'vedendo ch'ero per essere stroppiato per tutta la vita mia et che non mi sentivo niente, mi votai a' quel Quadro del beato da me cominciato'. As pointed out by Giovanni Ciappelli, the presence of Poccetti reporting the miraculous powers of the painting gave more prestige to the cause because of the importance of images in the post-Tridentine veneration of saints. Ciappelli 2007, 56.

${ }^{59}$ ASV Riti Proc. 762, f. 174r; see also f. 125r for a father testifying about his son.

${ }^{60}$ ASV Riti Proc. 762, f. 52r, 116v, 122v, 144v, 158r.

${ }^{61}$ ASV Riti Proc. 762, f. 138r. These kinds of remarks are rare, however. Although the physicians' task remained to testify to the fallibility of their art, the witness accounts rarely refer to any doubts regarding the physicians' skills. Didier Lett (2016) writes that in the end, physicians who 'failed' and then testified to miraculous cures rather proved their own honour as professionals who had tried everything in their power and had given up when nothing was left to be done.
} 
Canonisation testimonies do not allow a modern reader to track down any 'actual' experience of illness or disability. Rather, we can only grasp a memory of an experience ${ }^{62}$ filtered through the theological and legal practices of the inquest, as well as the cultural patterns regarding the miraculous. It is nevertheless evident that the experience of (an eventually miraculously cured) infirmity was a much more multifaceted issue than it might at first appear, and there are traces of its social dimensions in the witness accounts. It is possible that in order to be better able to investigate the exact nature, the commissioners required the more thorough investigation and recording of the witnesses' experiences in cases where the infirmities had less straightforward symptoms and consequences.

To start with, a couple of testimonies refer to the petitioner's inability to take care of their everyday tasks - a comment that would have been quite unnecessary in cases where the infirm person was unable to get out of bed or was in danger of dying. In one of these testimonies, the more specific functional consequences intermingle with the economic and medical aspects discussed above. Flametta Iacobi, a craftsman's wife and one of those categorising themselves as poor, broke her left arm. She received treatment as an outpatient at Santa Maria Nuova. ${ }^{63}$ A surgeon named Bamberino treated her. Her bones were 'put together' and she was sent home with some ointments, but to no avail. Her testimony mentions that she was unable to do her tasks or use her fingers, and she was in pain. ${ }^{64}$

Her husband's testimony adds another layer to the narration. According to him, Flametta broke her arm because of a fall she suffered after he pushed her during an argument. ${ }^{65}$ Although not emphasised in the records, the case is an example of a saint helping in a troubled or violent family situation. ${ }^{66}$ The husband also referred to Flametta's inability to work and the return of the ability to do so after the miracle, and this presented as the most crucial manifestation of the case. A broken arm was not necessarily visible to bystanders, nor did it threaten Flametta's life; therefore, it was her inability to contribute to the finances of the household underlined the severity of the condition.

\footnotetext{
${ }^{62}$ See Smoller 1998.

${ }^{63}$ Henderson 2006, 240-41.

${ }^{64}$ ASV Riti Proc. 762, f. 189v, 192r.

${ }^{65}$ ASV Riti Proc. 762, f. 222r.

${ }^{66}$ For hagiography and domestic violence, see Diana Bullen Presciutti's article in this volume.
} 
The social consequences of infirmity could be an important manifestation of a condition that did not hinder the person's functional abilities. Baptista Donati was cured of bleeding ulcers on his face, and his wife also testified to his cure. Apparently, his disfiguring condition caused public talk, since people gave different possible diagnoses, such as a 'ruined liver' (il fegato guasto). The infirmity lasted for five years, during which time he avoided interaction with others due to the shame the condition aroused in him. ${ }^{67}$ Baptista's inability to take care of his tasks is attributed to people who were 'disgusted' (schiffato) by his appearance; therefore, the disability it caused was mostly social. Remarks about disgust caused by infirmity are very rare in all the hagiographic material, although facial disfigurement features commonly in the medieval canonisation records. It is possible that people were indeed disgusted by disfigurement, and from the juridical and hagiographical point of view, these reports served the purpose of underlining the severity of a condition. ${ }^{68}$

Baptista's case is made even more intriguing by the diagnosis. The Italian word guasto translates as 'spoiled' or 'ruined'. In the trial records of the Italian inquisition from the same period, it is among the words commonly used to denote illness caused by maleficia ${ }^{69}$ Baptista's wife stated she did not know what the illness was. However, she also testified about the cures of their two small sons. One son had had a fever, but the other son's infirmity remained unnamed; according to her testimony, some people said that he 'was ruined/bewitched' (era stato guasto) ${ }^{70}$ There is no way of knowing for sure if some community members thought the ailment of Baptista or the child was of supernatural origin. If so, it is possible that this talk added to the communal consequences of their conditions, even if those whose infirmities were caused by bewitchment were considered victims and not culprits. In any event, the infirmity in Baptista's case was primarily a social one, and in his prayer to St Andrea, he precisely asked for a cure that would allow him to 'take care of his

\footnotetext{
${ }^{67}$ ASV Riti Proc. 762, f. 192r: 'le portai cinque anni che mi vergognavo a' companire et trattare con le persone'; ASV Riti Proc. 762, f. 168v: 'era una Cosa schiffosa a' vederlo et si vergognava di pratticare con le persone, le quali piaghe le porto da cinque anni et piu'.

68 See Kuuliala 2016, 116-17.

${ }^{69}$ See Breccola \& Lozzi 2007, 25-27; Seitz 2011, 12; O’Neil 1981, 63, 73, 85. For example, in the 1588 trial held in Siena of the local women Angelica di Gherardo and her daughter Antea, the inquisitor asked a witness if any woman had 'ruined' a child of his. Archivio della Congregazione per la Dottrina della Fede (ACDF), Proc. 17, f. 603r: 'Domandato se mai gl'e occorso che li sia da alcuna donna mai stato ammalato o guasto alcuno de suoi putti mentre sonno stati piccoli'. For the Siena trial, see Di Simplicio 2005.

${ }^{70}$ ASV Riti Proc. 762, f. 168v.
} 
duties'. ${ }^{71}$ This is a clear example of the mode of thought in which health meant the ability to fulfil one's social role. ${ }^{72}$

The skin conditions most often examined in canonisation inquests were ulcers and fistulas. In the case of the lay nun Angelica de Castel del Rio mentioned above, two other witnesses reported her being ashamed and hiding her hands. ${ }^{73}$ Here too, the diagnosis was something upon which the community did not wholly agree. Angelica herself was convinced of the leprosy diagnosis, but Magdalena de Sancta Sophia testified she did not know what the illness was called, but it was said in the household that a 'bad humour had gone down to her hands' ${ }^{74}$ According to the medical ideas of the time, all illness was caused by the imbalance of humours, but the diagnosis of leprosy was probably not convincing to all the community's members, since the infirmity only affected Angelica's hands. An interesting detail in Angelica's case is that she resided in the household of Rodrigo Alidosi, the ambassador of the Grand Duke of Tuscany Ferdinando I de Medici, due to a stipulation in the will of his father, Ciro Alidosi. Castel del Rio was Alidosi’s fief, which explains the connection, although its particularities are not known. ${ }^{75}$ Angelica was 53 years old at the time of the canonisation investigation, so apparently she had already lived in the household of Ciro Alidosi, who died in 1589. This connection secured her livelihood and position despite her illness, which could be severely disabling, both physically and socially.

\section{Cure and community}

The role of the community was strong when possible curative methods were negotiated and decided, and this is a point where lived religion and lived medicine overlap. Much has been written about the communal aspect of the veneration of saints, and it has been shown that

\footnotetext{
${ }^{71}$ ASV Riti Proc. 762, f. 192r: 'acciò potesse fare li fatti miei et trafficare nella mia arte che non ci potevo trafficare perche ero schiffato da tutti'.

${ }^{72}$ As another type of example of this, when the abbess of the Clarissan convent of Santa Maria di Monticellis testified about the cure of one of the nuns, she stated that she was doing 'the same things that the other nuns do'. ASV Riti Proc. 762, f. 294v.

${ }^{73}$ ASV Riti Proc. 762, f. 133r: 'si vergognava di pratticare tra li noi, et in Casa sempre le ascondeva'. The number of such unattached religious women was small, but the lifestyle still was possible. Strocchia 2009, 16162.

${ }^{74}$ ASV Riti Proc. 762, f. 133v: 'si diceva in casa che era un humore cattivo che li era calato li nelle mani'. See also page \#\#\# of Andreea Marculescu's article in this volume for leprosy miracles.

${ }^{75}$ For Rodrigo Alidosi, see Mayer 2014.
} 
invoking a saint was a social strategy. ${ }^{76}$ As the cases discussed above have already shown, a petition to a saint intermingled with other healing methods in miracle testimonies. As noted at the beginning of this article, this is part of the medical pluralism of the period, meaning that people turned to various forms of medical and religious assistance simultaneously. Medicine and religion were thus inseparable aspects of the experience of infirmity and healing, but they had to be differentiated for juridical purposes in canonisation records. The idea also existed that if the petitioner turned back to earthly medicine after asking for help from a saint, the saint could withdraw his or her help or even punish the petitioner. ${ }^{77}$

Sometimes the witness accounts in St Andrea's inquest refer to medical assistance given by non-licenced medical practitioners. Unsurprisingly, the presence of undefined donne was a standard statement in miracles related to childbirth, but their presence is sometimes hinted at in other testimonies too, ${ }^{78}$ offering an example of the gendered practices of healthcare within households. Bartholomea Petri de Sancto Donino, who had an ailment of the head, testified that the 'various opinions' (la diversita d'opinione) of people had not helped her, and her husband and daughter testified that she had used ointments given by unnamed women. ${ }^{79}$ Similarly, the mother of a boy run over by a carriage applied ointment given by an unnamed woman. ${ }^{80}$ The witnesses could also testify that they favoured the treatments of these people, like a woman with flux who did not want to take terra rossa (possibly iron oxide) ordered by a physician, but who took a potion made by an unnamed woman. ${ }^{81}$ The remedies of these empirics could also be more 'magical'. The aforementioned Antonia testified that when her son Agostino suffered from bleeding from the nose and mouth, no medicine was used; instead, 'certain women incanted the blood to make it stop'. ${ }^{82}$ The wife of Andreas Romuli, who had rissipola, testified that no medicina was used, but that he had had a woman 'signing' him. In another part of her testimony, she refers to the act as an incantation (fece incantare d'una Donna). Andreas himself and another woman said this woman 'signed' (segnare)

\footnotetext{
${ }^{76}$ See esp. Katajala-Peltomaa 2017.

77 Vauchez 1998, 531; Smoller 1997. Some late medieval canonisation records, which are not always as organised as those from the post-Tridentine era, give us glimpses of this. For example, in the Breton inquest records on duke Charles of Blois from the 1370s, a knight with war wounds first prayed to Charles and the Virgin Mary and then went to see Parisian surgeons, but he attributed his cure to the duke's miraculous powers. Biblioteca Apostolica Vaticana, MS Vat. lat. 4025, f. 121r-V.

78 See also Burkardt 2004, 292-97.

${ }^{79}$ ASV Riti Proc. 762, f. 37v, 76v, 80r.

${ }^{80}$ ASV Riti Proc. 762 , f. 135v. See f. $185 \mathrm{r}$ for a similar testimony by a woman with an ailing leg.

${ }^{81}$ ASV Riti Proc. 762, f. 146v.

${ }^{82}$ ASV Riti Proc. 762, f. 88v: 'certe donne incantauano il sangue per farlo cessare'.
} 
him. ${ }^{83}$ 'Signing' here means making the sign of the cross over an infirm person or body part with holy oil or a salve while often saying prayers or other orations. This is frequently reported in the healing miracles of living saints, and it was often performed by a priest or a lay healer. The term was so common that it could also simply refer to the act of curing. ${ }^{84} \mathrm{In}$ Andreas's case, it presumably referred to a more ritualistic practice, since the word incantare was used - in early modern court records, 'incantation' was a term that covered prayers, recipes, and secrets. ${ }^{85}$

In the testimonies, the witnesses present the remedies of these healers in the same manner as those of physicians and surgeons, simply stating that they were futile. In general, such references appear extremely rarely in canonisation documents, at least partly because references to unofficial healers and their skills were not juridically sufficient to prove a miracle. Another reason may be that a fine line existed between folk healing practices and sorcery, which the empirics and possibly their clients were aware of. ${ }^{86}$ At the same time, maleficia and various folk remedies began to emerge a little more frequently in the fifteenthcentury canonisation hearings than they did earlier, which presumably reflects the growing concern over maleficia at that point. ${ }^{87}$ The sporadic appearance of folk healers is nonetheless telling when we consider the varying pictures different source types provide about the lived religious and medical reality of the time. There is a seeming symmetry in that in principle, infirmities caused by sorcery or witchcraft were investigated by the Inquisition or secular courts, and the counterpoint of the 'witch', the exorcist, was able to cure such conditions. Miracle narratives, on the other hand, primarily concentrate on saints healing infirmities, which were caused 'naturally' ${ }^{88}$ In the lived medical reality of the period, unofficial healers

\footnotetext{
${ }^{83}$ ASV Riti Proc. 762, f. 141v-142r, 183r, f. 190r.

${ }^{84}$ Duni 2007; Seitz 2011, 78.

${ }^{85}$ O’Neil 2001, 175.

${ }^{86}$ Andrea Corsini's inquest does not give exact examples of this, but a testimony in the contemporary canonisation inquest of St Filippo Neri includes one such statement. Diana da Montopoli was treating a woman in labour whose child was stillborn. She was in possession of the saint's relic, and remembering this, decided to try if it would help. She put a pouch under the child, but according to her testimony, she did it in secret because they 'have many prohibitions on this, and she doubted that she would be considered a witch'. Il Primo processo, 4: 'Mentre lo raccomandai, mise la saccoccia sopra il putto, così segretamente, et mi palpava di farlo, che le genti si accorgessero, perchè noi havemo molte prohibitioni sopra di questo, et dubitava, che non mi tenessero per strega'.

${ }^{87}$ See O’Neil 2001, 172-99; Mormando 1999, 72-77, for this development, and Jacobs 2013, 171-72 for maleficia in miracles.

${ }^{88}$ Most often the infirmity simply 'arrives' or 'takes over' its victim, as if it was a separate entity. Gentilcore $1998,182$.
} 
may have been the primary group to turn to if there were doubts about the 'supernatural' origins of an infirmity, ${ }^{89}$ but their assistance was sought for all kinds of health problems. Physicians were also reported to have treated infirmities caused by sorcery, but unsuccessfully; often their failure was one reason for the diagnosis. ${ }^{90}$

Canonisation testimonies rarely reveal who suggested the healing methods of these donne, physicians, surgeons, or other healers, aside from the sporadic references to discussions within families. When it comes to a miraculous cure, the situation is somewhat different. In the case of an adult beneficiary, most witnesses did not mention the person who suggested it or reported having had the idea after reading or hearing Andrea's vitae..$^{91}$ Sometimes they referred to their usually unnamed community members. For example, in the case of a woman with a wound in her stomach, the witnesses referred to 'various women' (diverse donne) who visited her and said she should ask for St Andrea's help. ${ }^{92}$ In the case of a small boy with a falling sickness that was considered fatal, 'many women' were present when a neighbour was asked to go to fetch St Andrea's relics. Although the testimonies do not directly say so, this was most likely communally decided..$^{93}$ These testimonies present St Andrea's fama as a well-established aspect of the lived religious milieu of late-sixteenth- and early seventeenthcentury Florence. Although the miracle testimonies primarily focus on individual experiences, they also reflect the way 'people construct their religious worlds together' ${ }^{94}$ It is worth pointing out, however, that a canonisation inquest only shows one fraction of this 'religious world', as it focuses on only one cult. Help from other saints was not usually reported. One exception is the testimony of sister Lucretia of the Clarissan convent of Santa

\footnotetext{
${ }^{89}$ See Burkardt 2004, 296, who suggests this. In central Italian villages, there was a system where cunning men or women (indovino or indovina) were able to detect harmful magic. Di Simplicio 2009, 123.

${ }^{90}$ Oscar Di Simplicio points out that turning to unlicensed medical practitioners was especially common in rural areas due to the scarcity of official medical personnel and the cost of their services. Di Simplicio 2005, 83. One example of medical professionals treating an illness caused by black magic is recorded in St Bernardino of Siena's inquest, where a woman whose illness was caused by maleficium is reported as having used the help of physicians and incantations in the articulus; in her own testimony, she only refers to 'sortilegious remedies': Pellegrini 2009, 123. In the trials of the Inquisition, there are examples of this as well. In the Siena trials, a Franciscan friar testified about his gruesome illness caused by bewitchment, for which he first sought treatment by physicians. ACDF, Proc. 4, f. 566r. Possibly these infirmities were diagnosed as being of supernatural origin only after the physicians' treatment failed, but that is not always explicitly stated.

${ }^{91}$ See e.g. ASV Riti Proc. 762, f. 64r-v: 'prima che mi raccomandasse al Beato havendo sentito leggere la vita sua per doi mesi'. See also Thomas C. Devaney's article in this volume on the importance of books in spreading cults.

${ }^{92}$ ASV Riti Proc. 762, f. 32r.

${ }^{93}$ ASV Riti Proc. 762, f. 114r, 120r.

94 See McGuire 2008.
} 
Maria di Monticellis, who reported that she had asked for help from many saints, including St Raymond of Penyaforte, before turning to St Andrea. ${ }^{95}$

In this particular process, asking for help from the saint does not appear to be notably gendered. ${ }^{96}$ In general, taking care of the infirm was primarily a female concern, although we know quite little about the experience of nursing within the households of the early modern period, and men took part in it too. ${ }^{97}$ At the same time, in Renaissance Italy, it was the responsibility of both parents to find treatment for their ill children. ${ }^{98}$ In St Andrea's miracles, the petitioner in the majority of cases was the adult patient him- or herself. Other people making a vow for them include one wife and one husband, one daughter and one son, and some other family members. In the case of the twelve children whose cures were recorded, the mother made the vow in five of the cases. One case is unclear regarding the petitioner's identity. The father took the initiative in two or three cases (in the third one the witnesses disagree whether it was the father or both parents together)..$^{99}$ Others asking for a miracle for a child were two grandmothers, a sister, and a father's friend. The sample is too small to draw any far-reaching conclusions, but at least it shows that finding a cure for a child was the preference of a wider network of people.

The concept of 'lived religion' does not exclude the influence of the clerical elite, as they belonged to the same network that created and maintained a cult. Canonisation testimonies often present the members of the saint's order as active in spreading the word about the saint's miraculous powers. In Andrea Corsini's case, the Carmelites gave advice on praying to him and distributed his portable relics, most often chains or a hair shirt, to be placed on the ailing person's skin. Although relics were also privately owned, in this particular process the Carmelites appear as the sole controllers of them, acting like healers themselves, rushing out to the city whenever help was needed. This was commonly recorded especially in childbirth

\footnotetext{
95 ASV Riti Proc. 762, f. 292r.

96 This aspect has been studied in medieval miracles, especially in the case of child beneficiaries. In them, a mother is generally more often the one making the petition, but there is also a geographical difference in the sense that Scandinavian fathers sought out saintly assistance more often compared to their southern European peers. Finucane 2000, 99-100; Katajala-Peltomaa 2009, esp. 115-20; Katajala-Peltomaa 2013; Lett $1997,141$.

97 Stolberg 2011, 55.

${ }^{98}$ Haas 1998, 162.

99 This is somewhat common, because usually the 'hero' of the events was the petitioner or the person who had the idea for the successful petition: Smoller 1998, 435.
} 
miracles. ${ }^{100}$ The Carmelites' actions closely interacted with those of the devotees.

Descriptions of the relics also reveal the collaboration between various community members in receiving the sacred object. For example, when Elisabetta Petri de Caccarelli, who had fever and epilepsy, learned that her neighbour Sandro was going to ask for the relics for his sick daughter, she asked if he could let her touch them as well. ${ }^{101}$ Clearly, the Carmelites had nothing against such wishes, since her request was fulfilled. Women could ask for the relics, as Bartholomea Bartholomei Battiloro did to receive help for her brother Agostino; ${ }^{102}$ undoubtedly this kind of activity was undertaken only by women of a lower social standing.

With some infirmities, the role of the religiosi appears even more profound. This was especially the case with demonic possession miracles, which were recorded twice in the hearing. The condition is relatively unusual in the early modern processes, and in contemporary discussion, it often overlaps with physical symptoms and madness, while still being a category of its own. ${ }^{103}$ At the same time, a saint performing an exorcism was a common topic in the Catholic Reformation campaigns for opening up canonisation investigations, and depictions of exorcisms appeared in promotional pictures of shrines. ${ }^{104}$ These cases were thus powerful demonstrations of Andrea Corsini's sainthood within the lived religious system. In both cases, the condition was attributed to bewitchment or black magic (sortilegia); ${ }^{105}$ this combined with the somewhat ambivalent position of such miracles likely explains the amount of detail needed for proof.

Maria Baptista Gregorii's condition started as a 'malady', and her husband Baptista (whose cure was discussed above) arranged for a confessor, Ambroggio Carmelitano, to come and visit her. Maria was diagnosed as being possessed when she refused to make confession, so Ambroggio sent for the sacristan to bring the relics. When the sacristan arrived, the spirits started to take over Maria, but with the help of the relic, the sacristan managed to expel them.

\footnotetext{
${ }^{100}$ E.g. ASV Riti Proc. 762, f. 7v, 40r, 50v, 53r, 85v, 86r, 101v, 109r, 116r-v, 122r, 153r, 156v, 189v, 302r-v. The relics of St Andrea were not the only ones actively distributed to bring help to such situations in sixteenthcentury Florence. Similarly, the mitre of St Antoninus of Florence was often taken to help with childbirth problems. Cornelison 2017, 54.

${ }^{101}$ ASV Riti Proc. 762, f. 181v, 247r.

102 ASV Riti Proc. 762, f. 88r.

${ }^{103}$ Duffin 2009, 103-06; for possession in medieval canonisation documents, see Katajala-Peltomaa 2014. See also Andreea Marculescu's article in this volume.

104 Jacobs 2013, 172-74.

105 ASV Riti Proc. 762, f. 34v, 192r.
} 
Baptista testified that the friars in particular had told him that a malia had exited Maria's body; therefore their role was crucial not only in the cure but in the diagnosis as well. ${ }^{106} \mathrm{In}$ the case of magnifica domina Elisabetta Seraglia, the possession had prevailed for seven years, and visits to various churches had been of no use. The lady had lucid moments as well, because her servant testified that it was only after she had decided to go the church of the Carmelites that the spirits had started to torment her. ${ }^{107}$ According to Elisabetta, she first went to Santa Maria del Fiore in order to confess to the Archpriest, and asked to see the exorcist of the Carmelites. She eventually made it to the church despite the spirits' protests, and she was finally cured at Andrea's shrine, where the exorcist made her say 'many orations and litanies'. ${ }^{108}$ These testimonies portray a harmonious relationship between the clerics, the exorcist, and the miraculous. Although this was not always the case, ${ }^{109}$ there was a belief that exorcism was most efficient if performed on holy ground, in presence of relics, or in the vicinity of miracle-working images. ${ }^{110}$ Neither Maria nor Elisabetta were reported to have used any medicine, although sometimes reports of medicine being used were made too. ${ }^{111}$ The exorcist and the sacred, the two official counterparts of the demons and maleficia, were thus the only recourse.

\section{Conclusion}

In the discussion above, I hope to have demonstrated the opportunities the early modern canonisation processes provide for the study of lived religion and its interplay with healing. As religion - and saints' cults as a vital part of it - was a profound aspect of communal relations, it was interwoven into the various phases of human life, health issues included. The witnesses to miracles defined their infirmities largely in medical terms, trusting in physicians' skills and verdicts. Medicine and religion thus complemented each other not only on an official, theological level but in communal mindsets as well. At the same time, there was another, social level to some infirmities, which reportedly caused financial problems or social issues. These references portray the saint as bringing relief to the communal situation caused

\footnotetext{
106 ASV Riti Proc. 762, f. 192r-93r.

${ }^{107}$ ASV Riti Proc. 762, f. 238r-v.

108 ASV Riti Proc. 762, f. 279r-v.

109 See Ferber 2013, 66-68, for the tension regarding personal charismatic - even miraculous - powers and the institutional control of exorcism. See also Gentilcore 1998, 15-16.

110 Jacobs 2013, 172.

${ }^{111}$ Duffin 2009, 103.
} 
by infirmity, showing the role of the holy in mending and fixing various aspects of everyday life.

It is evident that canonisation testimonies show only one fragment of the interplay of religious and mundane healing. Just as religious and mundane healing were inseparable, so too were 'permitted and 'unorthodox' healing practices, and they were equally something that the community had to decide upon. The legitimacy of various spiritual and medical healing methods was constantly controlled and negotiated; their different levels of acceptability had a crucial impact on the ways they were portrayed in the documents. Saints always appear as supreme healers in the records, but in the everyday life of the communities, the situation was more multifaceted and the various folk healers belonged to the same religio-medical milieu. By venerating a saint, people created and lived a true community through their ritual acts and experiences, which they shared and reported both officially and unofficially. The role of lived religion is inseparable from the official proof of a miracle. It formed a fama publica and played a vital role in investigating and proving it, while the whole process of securing a cult strengthened the religious community venerating a particular saint, not to mention the whole idea of sainthood in general. Thaumaturgic cures - and especially their possibility and the negotiations leading to seeking help from a saint - inseparably link the variety of human conditions to this system, where symptoms and a cure become a way to give a grounding to the holy.

\section{Bibliography}

\section{Archival sources}

Vatican City

$\underline{\text { Archivio della Congregazione per la Dottrina della Fede (ACDF) }}$

Siena, Processus 17

\section{Archivio Segreto Vaticano (ASV)}

Riti Processus 762

Biblioteca Apostolica Vaticana (BAV) 
MS Vat. lat. 4025

\section{Printed Sources}

Cristofani, Federico. 1629. Vita di S. Andrea Corsini fiorentino dell'ordine Carmelitano vescouo di Fiesole. Florence.

Giussani, Giovanni Pietro. 1613. Vita di s. Carlo Borromeo, prete cardinale del titolo di Santa Prassede. Milan.

Martinelli, Serena Spanò, ed. 2003. Il Processo di canonizzazione di Caterina Vigri (15861712). Florence: Sismel, Edizioni del Galluzzo.

Pellegrini, Letizia ed. 2009. Il Processo di canonizzazione di Bernardino da Siena (14451450). Grottaferrata: Frati editori di Quaracchi.

della Rocchetta, Giovanni Incisa and Nello Vian with P. Carlo Gasparri d. O. ed. 1958. Il Primo processo per San Filippo Neri nel codice vaticano latino 3798 e in altri esemplari dell 'archivio dell'oratorio di Roma, vol. II: Testimonianze dell'inchiesta romana: 15961609. Città del Vaticano: Biblioteca Apostolica Vaticana.

Societé des Bollandistes, ed. 1863-. Acta sanctorum quotquot toto urbe coluntur. Brussels \& Antwerp: Société des Bollandistes.

\section{Literature}

Bouley, Bradford A. 2017. Pious Postmortems: Anatomy, Sanctity, and the Catholic Church in Early Modern Europe. Philadelphia: University of Pennsylvania Press.

Breccola, Giancarlo and Mario Lozzi. 2007. Il Paese delle streghe. Con un inédito proceso per stregoneria nella Tuscia viterbese. Latera: Annulli Editori. 
Burkardt, Albrecht. 2004. Les Clients des saints. Maladie et quête du miracle à travers les procès de canonisation de la première moitié du XVII siècle en France. Rome: École Française de Rome.

Burke, Peter. 1987. 'How to Be a Counter-Reformation Saint?' In Peter Burke, The Historical Anthropology of Early Modern Italy: Essays on Perception and Communication. Cambridge: Cambridge University Press, 48-62.

Ciappelli, Giovanni. 2007. Un Santo alla battaglia di Anghiari. La "vita" e il culto di Andrea Corsini nella Firenze del Rinascimento. Florence: Sismel.

Cohn, Samuel Kline. 1980. The Labouring Classes in Renaissance Florence. New York and London: Academic Press.

Copeland, Clare. 2016a: Maria Maddalena de' Pazzi: The Making of a Counter-Reformation Saint. Oxford: Oxford University Press.

Copeland, Clare. 2016b: 'Sanctity.' In The Ashgate Research Companion to the CounterReformation, ed. Alexandra Bamji, Geert H. Janssen, and Mary Laven. London and New York: Routledge, 225-42.

Cornelison, Sally J. 2017. Art and the Relic Cult of St. Antoninus in Renaissance Florence. London and New York: Routledge.

Debby, Nirit Ben-Aryeh. 2014. The Cult of St Clare of Assisi in Early Modern Italy. Aldershot: Ashgate, 2014.

Di Simplicio, Oscar. 2005. Autunno della stregoneria. Maleficio e magia nell'Italia moderna. Bologna: Il Mulino.

Di Simplicio, Oscar. 2009. 'Giandomenico de Fei, the Only Male Witch. A Tuscan or an Italian Anomaly?' In Witchcraft and Masculinities in Early Modern Europe ed. Alison Rowlands. New York: Palgrave MacMillan, 121-48. 
Ditchfield, Simon. 1995. Liturgy, Sanctity and History in Tridentine Italy. Pietro Maria Campi and the Preservation of the Particular. Cambridge: Cambridge University Press.

Ditchfield, Simon. 2009. 'Thinking with Saints: Sanctity and Society in the Early Modern World.' Critical Inquiry 35, 552-84.

Ditchfield, Simon. 2010. 'Coping with the "beati moderni'. Canonisation procedure in the aftermath of the Council of Trent.' In Ite infiammae omnia ed. Tom McCoog. Rome: Institutum historicum societatis iesu, 413-39.

Duffin, Jacalyn. 2009. Medical Miracles: Doctors, Saints and Healing in the Modern World. Oxford: Oxford University Press.

Duni, Matteo. 2007. Under the Devil's Spell: Witches, Sorcerers, and the Inquisition in Renaissance Italy. Syracuse: Syracuse University Press.

Ferber, Sarah. 2013. Demonic Possession and Exorcism: In Early Modern France. London and New York: Routledge.

Finucane, Ronald C. 2000. The Rescue of the Innocents. Endangered Children in Medieval Miracles. New York: St. Martin's Press.

Gentilcore, David. 1998. Healers and Healing in Early Modern Italy. Manchester: Manchester University Press.

Goldthwaite, Richard A. 2009. The Economy of Renaissance Florence. Baltimore: JHU Press.

Goodich, Michael. 2005. 'Mirabilis Deus in sanctis suis. Social History and Medieval Miracles.' In Signs, Wonders, Miracles. Representations of Divine Power in the Life of Church, ed. Kate Cooper and Jeremy Gregory. Woodbridge: Boydell \& Brewer, 135-56.

Goodich, Michael. 2007. Miracles and Wonders. The Development of the Concept of Miracle, 1150-1350. Aldershot: Ashgate. 
Haas, Louis. 1998. Renaissance Man and His Children. Childbirth and Early Childhood in Florence, 1300-1600. New York: Palgrave Macmillan.

Henderson, John, 2006. The Renaissance Hospital: Healing the Body and Healing the Soul. New Haven: Yale University Press.

Jacobs, Fredrika H., 2013. Votive Panels and Popular Piety in Early Modern Italy. Cambridge: Cambridge University Press.

Katajala-Peltomaa, Sari. 2009. Gender, Miracles and Daily Life. The Evidence of FourteenthCentury Canonization Processes. Turnhout: Brepols.

Katajala-Peltomaa, Sari. 2013. 'Fatherhood, Masculinity and Lived Religion in Late Medieval Sweden.' Scandinavian Journal of History 28, 223-44.

Katajala-Peltomaa, Sari. 2014. 'Demonic Possession as Physical and Mental Disturbance.' In Mental (Dis)Order in Later Medieval Europe, ed. Sari Katajala-Peltomaa and Susanna Niiranen. Leiden: Brill, 108-26.

Katajala-Peltomaa, Sari. 2017. 'Devotional Strategies in Everyday Life: Laity's Interaction with Saints in the North in the Fourteenth and Fifteenth Centuries.' In Lived Religion and the Long Reformation in Northern Europe c. 1300-1700, ed. Sari Katajala-Peltomaa and Raisa Maria Toivo. Leiden: Brill, 21-45.

Katajala-Peltomaa, Sari and Raisa Maria Toivo. 2016. 'Religion as an Experience.' In Lived Religion and the Long Reformation in Northern Europe c. 1300-1700. Leiden: Brill, 1-19.

Klaniczay, Gábor. 2000. 'Miracoli di punizione e maleficia.' In Miracoli. Dai segni alla storia, ed. Sofia Boesch Gajano and Marilena Modica. Roma: Viella, 2000, 109-36.

Klaniczay, Gábor, ed. 2004. Procès de canonisation au Moyen Âge. Aspects juridiques et religieux. Rome: École Française de Rome. 
Krötzl, Christian. 1998. 'Prokuratoren, Notare und Dolmetscher. Zu Gestaltung und Ablauf der Zeugeneinvernahmen bei spätmittelalterlichen Kanonisationsprozessen.' Hagiographica 5: 119-40.

Krötzl, Christian. 2000. 'Miracles au tombeau - miracles à distance. Approches typologiques.' In Miracle et Karama. Hagiographies médiévales comparées, ed. Denise Aigle. Turnhout: Brepols, 2000, 557-76.

Kuuliala, Jenni. 2015. 'Nobility, Community, and Physical Disability in Later Medieval Canonization Processes.' In Infirmity in Antiquity and the Middle Ages: Social and Cultural Approaches to Health, Weakness and Care, ed. Christian Krötzl, Katariina Mustakallio, and Jenni Kuuliala. Aldershot: Ashgate, 67-82.

Kuuliala, Jenni. 2016. Childhood Disability and Social Integration in the Middle Ages. Constructions of Impairments in Thirteenth-and Fourteenth-Century Canonization Processes. Turnhout: Brepols.

Lett, Didier. 1997. L'enfant des miracles. Enfance et société au Moyen Âge (XIIe-XIIIe siècle). Paris: Aubier.

Lett, Didier 2016. 'Judicium Medicine and Judicium Sanctitatis. Medical Doctors in the Canonization Process of Nicholas of Tolentino (1325): Experts Subject to the Inquisitorial Logic.' In Church and Belief in the Middle Ages: Popes, Saints, and Crusaders, ed. Sari Katajala-Peltomaa and Kirsi Salonen. Amsterdam: Amsterdam University Press, 153-70.

Mayer, Thomas F. 2014. The Roman Inquisition on the Stage of Italy, C. 1590-1640. Philadelphia: University of Pennsylvania Press.

McGuire, Meredith. 2008. Lived Religion: Faith and Practice in Everyday Life. Oxford: Oxford University Press.

Mormando, Franco. 1999. The Preacher's Demons. Bernardino of Siena and the Social Underworld of Early Renaissance Italy. Chicago and London: University of Chicago Press. 
O’Neil, Mary. 1981. Discerning Superstition: Popular Errors and Orthodox Response in Late Sixteenth Century Italy. Unpublished PhD Thesis, Stanford University.

O’Neil, Mary. 2001. 'Magical Healing: Love Magic and the Inquisition in Late SixteenthCentury Modena.' In Witchcraft, Healing, and Popular Diseases: New Perspectives on Witchcraft, ed. Brian P. Levack. London and New York: Routledge, 172-99.

Paciocco, Roberto. 2006. Canonizzazioni e culto dei santi nella christianitas (1198-1302). Assisi: Edizioni Porziuncola.

Papa, Giovanni. 2001. Le Cause di canonizzazione nel primo periodo della Congregazione dei Riti (1588-1634). Rome: Urbaniana University Press.

Pomata, Gianna. 1998. Contracting a Cure. Patients, Healers, and the Law in Early Modern Bologna. Baltimore: The Johns Hopkins University Press.

Seitz, Jonathan. 2011. Witchcraft and Inquisition in Early Modern Venice. Cambridge: Cambridge University Press.

Sigal, Pierre-André. 1985. L'homme et le miracle dans la France médiévale (XI $-X I I^{e}$ siècle). Paris: Les Éditions du Cerf.

Smoller, Laura Ackermann. 1997. 'Defining the Boundaries of the Natural in FifteenthCentury Brittany: The Inquest into the Miracles of Saint Vincent Ferrer (d. 1419).' Viator 28: $333-60$.

Smoller, Laura Ackermann. 1998. 'Miracle, Memory, and Meaning in the Canonization of Vincent Ferrer, 1453-54.' Speculum 73: 429-54.

Stolberg, Michael. 2011. Experiencing Illness and the Sick Body in Early Modern Europe. New York: Palgrave MacMillan.

Strocchia, Sharon. 2009. Nuns and Nunneries in Renaissance Florence. Baltimore: The Johns Hopkins University Press. 
Tacconi, Marica. 2005. Cathedral and Civic Ritual in Late Medieval and Renaissance Florence: The Service Books of Santa Maria Del Fiore. Cambridge: Cambridge University Press.

Vauchez, André. 1998. La sainteté en Occident aux derniers siècles du Moyen Âge. D'après les procès de canonisation et les documents hagiographiques. Rome: École française de Rome.

Ward, Benedicta. 1982. Miracles and the Medieval Mind. Theory, Record and Event 1000 1215. London: Scholar Press.

Ziegler, Joseph. 1999. 'Practitioners and Saints: Medical Men in Canonization Processes in the Thirteenth to Fifteenth Centuries.' Social History of Medicine 12: 191-225. 